\title{
PENGARUH EDUKASI MENGGUNAKAN LEAFLET, AUDIO VISUAL, LEAFLET DAN AUDIO VISUAL TERHADAP PENGETAHUAN, SIKAP DAN PERILAKU ORANGTUA DALAM PENCEGAHAN DIARE DI PUSKESMAS RAWAT INAP MANIS JAYA TANGERANG
}

\author{
Rianti $^{1)}$, Anita Apriliawati ${ }^{1)}$, Suhendar Sulaiman ${ }^{2)}$ \\ ${ }^{1}$ Fakultas Keperawatan Universitas Muhammadiyah Jakarta \\ ${ }^{2}$ Fakultas Keperawatan Universitas Muhammadiyah Jakarta \\ E-mail : rianti.riri66@gmail.com
}

\begin{abstract}
Diarrhea in infants and toddlers (under five years) can be very dangerous because it can cause death. The death is caused by lack of fluid that comes out with a lot of feces. The purpose of this study is to determine the influence of education using leaflets, audiovisuals, leaflets and audiovisuals on parental behavior in preventing diarrhea in toddlers (under five years old). This study is using Quasi-Experimental design with a Pretest-Posttest Group Design approach. The sample in this study is 27 samples. The test results found there are differences on parent's knowledge, attitudes and behavior before and after health education was given using Leaflets, Audiovisuals, Leaflets and Audiovisuals with $p$ value $<0.005$. It found the difference on parent's knowledge, attitude and behavior before and after given the health education using leaflet with each $p$ value $<0,001,0,010,0,019$. found the difference on parent's knowledge, attitude and behavior before and after given the health education using audiovisual with each $p$ value $<0,001,0,001$. 0,001. It found the difference on parent's knowledge, attitude and behavior before and after given the health education using leaflet and audiovisual with p value< 0,001, 0.012, 0,001). The hope is for educators to improve health promotion, especially prevention of diarrhea by playing diarrhea prevention videos, so that the dissemination of this information is broader and useful for all patients, not only diarrhea patients.
\end{abstract}

Keyword : Toddler, Leaflets, Audiovisual Leaflets And Audivisual, Knowledge, Attitudes, Mother's Behavior 


\section{. PENDAHULUAN}

Penyebab utama diare adalah minimnya perilaku hidup bersih dan sehat di masyarakat. Diare juga berkaitan dengan kebersihan perorangan dan memiliki perilaku hidup sehat. Diare berhubungan dengan penggunaan jamban keluarga dan penggunaan air bersih. Diare tidak berhubungan dengan faktor pembuangan sampah dan kebiasaan mencuci tangan namun, kepadatan hunian dalam suatu rumah tangga, termasuk malnutrisi pada anak balita, ternyata berpengaruh terhadap kejadian diare (Hidayat, 2008).

Kematian pada diare diakibatkan oleh kekurangan cairan yang banyak keluar bersama tinja. Menurut Survey Demografi dan Kesehatan Indonesia (2017), dehidrasi karena diare merupakan penyebab utama kematian pada bayi dan anak dan kondisi ini dapat diatasi dengan rehidrasi oral. Rehidrasi oral telah direkomendasikan untuk mengatasi diare. Rehidrasi oral yang tersedia dapat berupa paket oralit (garam rehidrasi oral), larutan gula garam dan minum lebih banyak. Pemberian rehidrasi oral dapat dilakukan sebagai salah satu penatalaksanaan, sehingga dapat mencegah terjadinya komplikasi yaitu dehidrasi dan gangguan gizi akibat diare serta akan mempercepat penyembuhan (USAID, UNICEF \& WHO, 2015). Penatalaksanaan lain yang juga dapat dilakukan untuk menghindari komplikasi adalah Diperlukan pemahaman Orang tua tentang pencegahan diare Peran perawat dalam menurunkan angka kejadian diare memberikan Pendidikan kesehatan untuk mencegah diare. tetap memberikan makanan yang dianjurkan dengan porsi seperti biasa (SDKI,2017).

Di negara berkembang seperti Indonesia diare masih menjadi masalah kesehatan masyarakat. Indonesia memiliki insidensi dan mortalitas yang tinggi pada kasus ini. Diperkirakan 20-50 kejadian diare per 100 penduduk setiap tahunnya. Berdasarkan Riset Kesehatan Dasar (Riskesdas) tahun 2018 menyatakan angka prevalensi diare di Indonesia masih berfluktuasi. Periode prevalen diare di Indonesia saat ini adalah 518\% kejadian. Angka ini sudah turun dibandingkan hasil Riskesdas 2013 yaitu 3,5\% dengan rentang 4,2\%-18,9\%. Data nasional menyebutkan setiap tahunnya di Indonesia 100.000 balita meninggal dunia karena diare. Hal tersebut berarti setiap hari ada 273 balita yang meninggal dunia karena diare,sama halnya dengan 11 jiwa meninggal setiap jamnya atau 1 jiwa meninggal setiap 5,5 menit akibat diare. Sebesar $70-80 \%$ penderita diare adalah balita. Menurut data Kementrian Kesehatan, diare merupakan penyakit kedua di Indonesia yang dapat menyebabkan kematian anak usia balita setelah radang paru atau pneumonia (Kemenkes, 2011).

\section{METODE}

Desain penelitian yang digunakan pada penelitian ini adalah desain penelitian Quasi-Experimental Design dengan menggunakan metode pendekatan Pretest-Posttest Group Design. Populasi dalam penelitian ini adalah ibu yang memiliki anak balita (12 bulan-59 bulan) dengan diare yang dirawat di Puskesmas Rawat Inap Manis Jaya. Sampel penelitian berjumlah 27 ibu. Penelitian ini dilakukan di Puskesmas Rawat Inap Manis Jaya . Pertimbangan pemilihan tempat penelitian karena banyaknya kejadian diare.

Penelitian ini dilaksanakan dimulai dari persiapan penelitian dan proposal diajukan pada bulan Februari Maret 2019, dan pengumpulan data dilakukan selama dua bulan, yaitu pada bulan April - Mei 2019.

Dalam penelitian ini proses pengambilan dan pengumpulan data diperoleh dengan kuesioner meliputi kuesioner pengetahuan, sikap dan perilaku yang sudah di uji rehabilitas dan valditas Di puskesmas Rawat inap manis jaya tanggerang.

Variabel dalam penelitian ini adalah variabel independen (bebas) yaitu leaflet dan audiovisual, variabel dependennya (terikat) adalah pengetahuan, sikap, perilaku kesehatan, 
Proses pengumpulan data dilakukan selama kurang lebih dua bulan dengan berkoordinasi dengan pihak penanggung jawab rawat inap.

Analisa data dilakukan secara univariat, bivariat dengan menggunakan uji statistik Paired T tes.

\section{HASIL DAN PEMBAHASAN}

Tabel 1 Gambaran Perubahan dan Rata-rata Pengetahuan Sebelum dan Sesudah diberikan Intervensi Edukasi Kesehatan menggunakan Leaflet

\begin{tabular}{lccccc}
\hline \multirow{2}{*}{$\begin{array}{l}\text { Kelompok } \\
\text { Intervensi }\end{array}$} & Waktu & \multicolumn{5}{c}{ Pengetahuan } \\
\cline { 3 - 6 } Peaflet & Sebelum & 9 & 25,89 & $24,38-27,40$ & \\
\cline { 3 - 6 } & Sesudah & 9 & 31,11 & $29,46-32-76$ & 5,222 \\
\hline \multirow{2}{*}{ Audiovisual } & Sebelum & 9 & 24,78 & $23,52-26,04$ & \\
& Sesudah & 9 & 30,56 & $29,53-31,58$ & 5,778 \\
\hline $\begin{array}{l}\text { Leaflet dan } \\
\text { Audiovisual }\end{array}$ & Sebelum & 9 & 26,00 & $24,78-27,22$ & \\
\hline & Sesudah & 9 & 30,56 & $29,53-31,58$ & 4,556 \\
\hline
\end{tabular}

Tabel 1 menunjukkan bahwa pengetahuan dari ketiga kelompok sebelum diberikan intervensi berada pada rentang diatas 20 yaitu pada kelompok leaflet dengan rata-rata 25,89 $(\mathrm{SD}=1,965)$ yang lebih tinggi dibandingkan kelompok audiovisual dengan rata-rata 24,78 $(\mathrm{SD}=1,641)$. Sedangkan pengetahuan rata-rata setelah perlakuan di kelompok leaflet dan audiovisual berada pada rentang diatas 30 yaitu pada $31,11(\mathrm{SD}=2,147)$

Tabel 2 Gambaran Perubahan dan Rata-rata Sikap Sebelum dan Sesudah diberikan Intervensi Edukasi Kesehatan menggunakan Audiovisual

\begin{tabular}{lccccc}
\hline \multirow{2}{*}{$\begin{array}{c}\text { Kelompok } \\
\text { Intervensi }\end{array}$} & $\begin{array}{c}\text { Waktu } \\
\text { Pengukuran }\end{array}$ & \multicolumn{5}{c}{ Sikap } \\
\cline { 3 - 6 } Leaflet & Sebelum & 9 & 47,33 & $44,28-50,38$ & \\
& Sesudah & 9 & 49,56 & $46,83-52,28$ & 2,222 \\
\hline & Sebelum & 9 & 41,67 & $39,91-43,43$ & \\
Audiovisual & Sesudah & 9 & 49,00 & $46,10-51,90$ & 7,333 \\
& & & & & \\
\hline $\begin{array}{l}\text { Leaflet dan } \\
\text { Audiovisual }\end{array}$ & Sebelum & 9 & 45,67 & $43,56-47,77$ & \\
\hline
\end{tabular}

Tabel 2 menunjukkan bahwa sikap dari ketiga kelompok sebelum diberikan intervensi berada pada rentang diatas 40 yaitu pada kelompok leaflet dengan rata-rata 47,33 ( $\mathrm{SD}=3,969)$ yang lebih tinggi 
dibandingkan kelompok audiovisual dengan rata-rata 41,67 $(\mathrm{SD}=2,291)$. Sedangkan sikap rata-rata setelah perlakuan di kelompok leaflet dan audiovisual berada pada rentang diatas 40 yaitu pada 49,67 $(\mathrm{SD}=3,279)$.

\section{Tabel 3 Gambaran Perubahan dan Rata-rata Perilaku Sebelum dan Sesudah diberikan Intervensi Edukasi Kesehatan menggunakan Leaflet dan Audiovisual}

\begin{tabular}{lccccc}
\hline Kelompok & Waktu & \multicolumn{4}{c}{ Perilaku } \\
\cline { 3 - 6 } Intervensi & Pengukuran & $\mathrm{N}$ & Mean & $95 \%$ CI & $\Delta$ \\
\hline \multirow{2}{*}{$\begin{array}{l}\text { Leaflet } \\
\text { Sebelum }\end{array}$} & 9 & 17,44 & $15,72-19,17$ & \\
& Sesudah & 9 & 19,89 & $17,67-22,11$ & 2,444 \\
$\begin{array}{l}\text { Audiovisua } \\
l\end{array}$ & Sebelum & 9 & 16,56 & $15,69-17,42$ & \\
\hline $\begin{array}{l}\text { Leaflet } \\
\text { dan }\end{array}$ & Sesudah & 9 & 21,44 & $20,00-22,89$ & 4,889 \\
$\begin{array}{l}\text { Audiovisua } \\
\text { S Sebelum }\end{array}$ & 9 & 17,22 & $15,74-18,70$ & \\
\hline
\end{tabular}

Tabel 3 menunjukkan bahwa sikap dari ketiga kelompok sebelum diberikan intervensi berada pada rentang diatas 15 yaitu pada kelompok leaflet dengan rata-rata $17,44(\mathrm{SD}=2,242)$ yang lebih tinggi dibandingkan kelompok audiovisual dengan rata-rata $16,56(\mathrm{SD}=1,130)$. Sedangkan sikap rata-rata setelah perlakuan di kelompok leaflet dan audiovisual berada pada rentang diatas 20 yaitu pada 21,44 $(\mathrm{SD}=1,878)$.

Tabel 4 Pengaruh Intervensi Edukasi Kesehatan menggunakan Leaflet terhdap Pengetahuan, Sikap dan Perilaku $(\mathbf{n}=27)$

\begin{tabular}{ccccc}
\hline $\begin{array}{c}\text { Kelompok } \\
\text { Intervensi }\end{array}$ & Sebelum & Sesudah & $\begin{array}{c}\mathrm{P} \\
\text { Value }\end{array}$ & $\Delta$ \\
\hline Pengetahuan & 25,89 & 31,11 & 0,001 & 5,22 \\
\hline Sikap & 47,33 & 49,56 & 0,010 & 2,23 \\
\hline Perilaku & 17,44 & 19,89 & 0,019 & 2,5 \\
\hline
\end{tabular}

Tabel 4 menunjukan nilai rerata pengetahuan sebelum diberikan Edukasi kesehatan menggunakan leaflet adalah 25,89 dan sesudah diberikan Edukasi kesehatan nilai rerata pengetahuan yaitu 31,11 adanya peningkatan sebesar 5,22 terhadap pengetahuan. Hasil uji nilai $\mathrm{p}$ value $<0,05$ dimana ada perbedaan tingkat pengetahuan sebelum dan sesudah diberikan Edukasi kesehatan menggunakan leaflet.
Tabel 4 menunjukan nilai rerata sikap sebelum diberikan Edukasi kesehatan menggunakan leaflet adalah 47,33 dan sesudah diberikan Edukasi kesehatan nilai rerata sikap yaitu 49,59 adanya peningkatan sebesar 2,23 terhadap sikap. Hasil uji nilai $p$ value $<0,05$ dimana ada perbedaan sikap sebelum dan sesudah diberikan Edukasi kesehatan menggunakan leaflet. 
Tabel 4 menunjukan nilai rerata perilaku sebelum diberikan Edukasi kesehatan menggunakan leaflet adalah 17,44 dan sesudah diberikan Edukasi kesehatan nilai rerata perilaku yaitu 19,89 adanya peningkatan sebesar 2,5 terhadap perilaku. Hasil uji nilai $\mathrm{p}$ value $<0,05$ dimana ada perbedaan perilaku sebelum dan sesudah diberikan Edukasi kesehatan menggunakan leaflet.

Tabel 5 Pengaruh Intervensi Edukasi Kesehatan menggunakan Audiovisual terhdap Pengetahuan, Sikap dan Perilaku $(\mathbf{n}=27)$

\begin{tabular}{ccccc}
\hline $\begin{array}{c}\text { Kelompok } \\
\text { Intervensi }\end{array}$ & Sebelum & Sesudah & $\begin{array}{c}\mathrm{P} \\
\text { Value }\end{array}$ & $\Delta$ \\
\hline Pengetahuan & 24,78 & 30,56 & 0,001 & 5,78 \\
\hline Sikap & 41,67 & 49,00 & 0,001 & 7,33 \\
\hline Perilaku & 16,56 & 21,44 & 0,001 & 4,89
\end{tabular}

Tabel 5 menunjukan nilai rerata pengetahuan sebelum diberikan Edukasi kesehatan menggunakan audiovisual adalah 25,78 dan sesudah diberikan Edukasi kesehatan nilai rerata pengetahuan yaitu 30,56 adanya peningkatan sebesar 5,78 terhadap pengetahuan. Hasil uji nilai $\mathrm{p}$ value $<0,05$ dimana ada perbedaan tingkat pengetahuan sebelum dan sesudah diberikan Edukasi kesehatan menggunakan audiovisual. esehatan nilai rerata sikap yaitu 49,00 adanya peningkatan sebesar 7,33 terhadap sikap. Hasil uji nilai $p$ value $<0,05$ dimana ada perbedaan sikap sebelum dan sesudah diberikan Edukasi kesehatan menggunakan audiovisual.

Tabel 5 menunjukan nilai rerata perilaku sebelum diberikan Edukasi kesehatan menggunakan audiovisual adalah 16,56 dan sesudah diberikan Edukasi kesehatan nilai rerata perilaku yaitu 21,44 adanya peningkatan sebesar 4,89 terhadap perilaku. Hasil uji nilai $p$ value $<0,05$ dimana ada perbedaan perilaku sebelum dan sesudah diberikan Edukasi kesehatan menggunakan audiovisual.

Tabel 6 Pengaruh Intervensi Edukasi Kesehatan menggunakan leaflet dan Audiovisual terhdap Pengetahuan, Sikap dan Perilaku $(\mathrm{n}=27)$

\begin{tabular}{ccccc}
\hline $\begin{array}{c}\text { Kelompok } \\
\text { Intervensi }\end{array}$ & Sebelum & Sesudah & $\begin{array}{c}\mathrm{P} \\
\text { Value }\end{array}$ & $\Delta$ \\
\hline Pengetahuan & 26,00 & 30,56 & 0,001 & 4,56 \\
\hline Sikap & 45,67 & 49,67 & 0,012 & 4,00 \\
\hline Perilaku & 17,22 & 21,44 & 0,001 & 4,22 \\
\hline
\end{tabular}

Tabel 6 menunjukan nilai rerata pengetahuan sebelum diberikan Edukasi kesehatan menggunakan leaflet dan audiovisual adalah 26,00 dan sesudah diberikan Edukasi kesehatan nilai rerata pengetahuan yaitu 30,56 adanya peningkatan sebesar 4,56 terhadap pengetahuan. Hasil uji nilai $p$ value $<0,05$ dimana ada perbedaan tingkat pengetahuan sebelum dan sesudah diberikan Edukasi kesehatan menggunakan leaflet dan audiovisual. 
Tabel 6 menunjukan nilai rerata perilaku sebelum diberikan Edukasi kesehatan menggunakan leaflet dan audiovisual adalah 17,22 dan sesudah diberikan Edukasi kesehatan nilai rerata perilaku yaitu 21,44 adanya peningkatan sebesar 4,22 terhadap perilaku. Hasil uji nilai $\mathrm{p}$ value $<0,05$ dimana ada perbedaan perilaku sebelum dan sesudah diberikan Edukasi kesehatan menggunakan leaflet dan audiovisual.

\section{PEMBAHASAN}

\section{Pengetahuan Sebelum dan Sesudah Edukasi Kesehatan}

Hasil penelitian didapatkan adanya perbedaan peningkatan pengetahuan sebelum dan sesudah diberikan pendidikan kesehatan.Nursalam dkk (2008) mengatakan pengetahuan adalah hasil tahu, dan terjadi setelah orang melakukan pengindraan terhadap suatu objek tertentu. Efendy (2009) mengatakan sebagian besar pengetahuan manusia diperoleh melalui mata dan telinga seperti poster, buklet,leaflet, slide atau informasi yang berupa tulisan dan informasi yang berbentuk suara seperti ceramah,edukasi atau video yang membantu menstimulasi penginderaan dalam proses pembelajaran.

Maulana (2009) mengatakan bahwa tujuan pendidikan kesehatan adalah untuk meningkatkan pengetahuan, mengubah sikap dan mengarahkan perilaku yang diinginkan oleh kegiatan.Menurut WHO, pendidikan esehatan memilik tujuan menjadikan kesehatan menjadi sesuatu yang bernilai dimasyarakat dan menolong individu agar mampu secara mandiri atau kelompok mengadakan kegiatan untuk mencapai tujuan hidup sehat.

Pada penelitian ini terjadi peningkatan pengetahuan yang cukup besar, dikarenakan materi yang disampaikan berfokus pada definisi diare, dan penanganan diare yang tepat sehingga tidak memakan waktu yang lama.Setelah itu dilakukan sesi tanya jawab untuk menggulang pembahasan materi yang telah dibahas. Hal ini sesuai dengan teori Djamarah, S. B, 2000 metode ceramah memiliki beberapa kelemahan salah satunya yaitu jika terlalu lama dapat membuat jenuh (Simamora, 2009).Menurut beberapa ahli mengatakan saat melakukan edukasi hadirin jarang mengingat semua yang didengarnya, dan sasaran utama adalah mendorong hadirin untuk memikirkan topik yang diceramahkannya. Maka sebaiknya menggunakan ringkasan yang menggambarkan hal-hal yang penting saja untuk membantu proses ingatan. Teknik lain adalah mengajukan pertanyaan yang berhubungan dengan isi ceramah. Cara ini dapat mendorong hadirin menyerap pengetahuan yang baru saja didapatnya (Van, 2012).

\section{Sikap Sebelum Dan Sesudah Edukasi Kesehatan}

Hasil penelitian menunjukan adanya perbedaan sikap sebelum dan sesudah diberikan pendidikan kesehatan.Sikap merupakan hal yang harus dipelajari dan dibentuk melalui pengalaman, latihan sepanjang perkembangan individu (Maulana, 2009). Proses pembentukan atau perubahan sikap hampir selalu dilakukan dengan adanya objek dan manipulasi situasi atau lingkungan, sehingga menghasilkan perubahan sikap yang dikehendaki. Media audiovisual pada penelitian ini memberikan informasi tentang diare, penatalaksanaan diare di rumah, dan tanda bahaya diare.Informasi ini selain dapat meningkatkan pengetahuan, juga dapat mempengaruhi perubahan sikap menjadi lebih baik. Proses perubahan terjadi diasumsikan karena kebutuhan responden akan informasi saat itu sedang meningkat seiring dengan peningkatan perawatan yang dibutuhkan oleh balita mereka. Dirawatnya balita mereka di rumah sakit karena penyakit diare akan memberikan pengalaman yang tidak menyenangkan dan tidak ingin kondisi ini terulang kembali juga menyebabkan terjadinya perubahan sikap.

Hasil penelitian lain yang sesuai adalah pengaruh pendidikan kesehatan dengan metode audio visual tentang cara perawatan bayi 
terhadap perubahan perilaku ibu primipara dalam perawatan bayi baru lahir (Suryani, 2008). Penelitian ini dilakukan dengan pemutaran video sebanyak satu kali dan menggunakan design one group pre test post test. Hasil penelitian menunjukkan ada perubahan pengetahuan, sikap dan ketrampilan ibu sebelum dan sesudah diberikan edukasi.Hasil penelitian Sari (2004) juga sesuai dengan hasil ada perubahan pengetahuan dan sikap ibu sebelum dan sesudah diberikan edukasi. Penelitian yang lain adalah penelitian dari Tram, et al. (2003) yang menunjukan bahwa setelah diberi pendidikan kesehatan pengetahuan dan sikap kelompok intervensi berbeda secara bermakna dengan kelompok kontrol.

\section{Perilaku Sebelum dan Sesudah Edukasi Kesehatan}

Hasil penelitian menunjukan adanya perbedaan perubahan perilaku sebelum dan sesudah diberikan pendidikan kesehatan, Diare dapat menyebar dan menginfeksi anak melalui empat faktor, yaitu food (makanan), feces (tinja), fly (udara), dan finger (tangan).Oleh karena itu, untuk mencegah agar penyakit ini tidak menyebar dan menular, cara yang paling praktis adalah memutuskan rantai penularan tersebut. Faktor kebersihan menjadi faktor yang penting untuk menghindari anak dari penyakit diare (Fida dan Maya (2012: 318).Perilaku pencegahan diare merupakan tindakan yang dilakukan oleh ibu balita untuk mencegah terjadinya diare pada balita. Perilaku ibu yang positif dalam pencegahan diare ditandai dengan pemberian makanan yang higienis, menyediakan air minum yang bersih, menjaga kebersihan perorangan, membiasakan mencuci tangan sebelum makan, buang air besar pada tempatnya,menyediakan tempat pembungan sampah yang memadai, memberantas lalat dan menjaga kebersihan lingkungan. Pencegahan diare pada balita juga dapat dilakukan dengan memberikan ASI eksklusif pada balita dan menghindari penggunaan botol susu. Ibu balita juga perlu menyimpan dan menyiapkan MPASI dengan baik, menggunakan air bersih dan melakukan cuci tangan dengan sabun, serta membuang tinja dengan benar (Wahyudi, 2009).

Pengetahuan merupakan faktor predeposisi dari perilaku. Sebelum seseorang mengadopsi perilaku (berperilaku baru) terlebih dahulu apa arti atau manfaat perilaku tersebut bagi dirinya atau keluarganya. Pengetahuan atau kognitif merupakan domain yang sangat penting untuk terbentuknya tindakan seseorang (overt behaviour). Penerimaan perilaku baru atau adopsi perilaku didasari oleh pengetahuan, kesadaran dan sikap yang positif, maka perilaku tersebut akan bersifat langgeng (long lasting). Sebaliknya, apabila perilaku itu tidak didasari oleh pengetahuan dan kesadaranakan tidak berlangsung lama.Jadi pentingnya pengetahuan disini adalah dapat menjadi dasar dalam merubah perilaku sehingga perilaku itu langgeng.

\section{KESIMPULAN}

Berdasarkan hasil penelitian yang dilakukan di Puskemas Rawat Inap Manis Jaya Kecamatan Jatiuwung, maka kesimpulan dalam penelitian ini yaitu pengetahuan responden sebelum dan sesudah diberikan edukasi kesehatan menggunakan leaflet dengan nilai $\Delta$ 5,23. Sikap responden sebelum dan sesudah diberikan edukasi kesehatan menggunakan leaflet dengan nilai $\Delta 2,23$. Perilaku responden sebelum dan sesudah diberikan edukasi kesehatan menggunakan leaflet dengan nilai $\Delta \quad 2,45$. Pengetahuan responden sebelum dan sesudah diberikan edukasi kesehatan menggunakan audiovisual dengan nilai $\Delta \quad 5,78 \quad$. Sikap responden sebelum dan sesudah diberikan edukasi kesehatan menggunakan audiovisual dengan nilai $\Delta 7,33$. Perilaku responden sebelum dan sesudah diberikan edukasi kesehatan menggunakan audiovisual $\Delta$ 4,89. Pengetahuan responden sebelum dan sesudah diberikan edukasi kesehatan menggunakan leaflet dan audiovisual dengan nilai $\Delta$ 4,56. Sikap responden sebelum dan sesudah diberikan 
edukasi kesehatan menggunakan leaflet dan audiovisual dengan nilai $\Delta 4,00$. Perilaku responden sebelum dan sesduah diberikan edukasi kesehatan menggunakan leaflet dan audiovisual dengan nilai $\Delta 4,22$.

\section{REFERENSI}

Bhutta, Z.A., (2011). Acute Gastroenteritis in Children. In: Nelson Textbook of Pediatrics. 19th ed. USA: Elsevier.

Chow, C. M., Leung, A. K. C., Hon, K. L., (2011). Acute Gastroenteritis : From Guideline to Real Life. Clinical and Experimental Gastroenterology

Dahlan, M. Sopiyudin. (2017). Statistik untuk Kedokteran dan Kesehatan. Deskriptif, Bivariat dan Multivariat Dilengkapi Aplikasi dengan Menggunakan SPSS. Seri 1. Edisi 6. Jakarta: Epidemiologi Indonesia

Fitriani, S. (2011). Promosi Kesehatan. Cetakan 1. Yogyakarta: Graha Ilmu.

Gibney, M.J., et al. (2009). Gizi Kesehatan Masyarakat. Jakarta: EGC.

Graha cendekia. (2009). Hubungan pengetahuan ibu tentang penanganan diare pada anak di rumah dengan derajad dehidrasi pada anak diare di RS.

Http://grahacendikia.wordpress.com/2009/04/17 /hubungan-pengetahuan-ibu- tentangpenanganan-diare-pada-anak-di-rumah-denganderajad-dehidrasi- pada-anak-diare-di-rs/. Diperoleh tanggal 28 Februari 2019.
Handy, (2016). Penyakit Langganan Anak. Jakarta : Pustaka Bunda

Hastono,. Sutanto, P. (2016). Analisis Data pada Bidang Kesehatan. Depok: Rajagrafindo Persada

Hasdianah, HR., (2014). Gizi, Pemanfaatan Gizi, Diet, dan Obesitas. Yogyakarta: Nuha Medika

Hidayat, A., A. (2017). Metodologi Penelitian Keperawatan dan Kesehatan. Jakarta: Salemba Medika

Hidayat. (2008). "Hubungan Antara Penggunaan Sumber Air dan Kebiasaan PHBS (Perilaku Hidup Bersih dan Sehat) dengan Kejadian Diare di Desa Sawahan Kecamatan Ngemplakabupaten Boyolali Tahun (2008). Skripsi. Surakarta: Universitas Muhammadiyah Surakarta.

Hockenberry, M.J., Wilson, D. (2011). Won g's Book $2 \mathrm{Nu} r s$ ing Care of Inf ant $s$ a nd Children. Edition 9. Mosby Elseiver. USA.

Jumain. (2008). Gambaran pengetahuan dan sikap ibu tentang penyakit diare terhadap tingkat dehidrasi diare pada balita. Http://www.adln.lib.unair.ac.id/go.php?id=gdlh ub-gdl-sl-2008-jumain-

$8533 \& q=$ sikap $+i b u+$ diare. Diperoleh tanggal 23 Februari 2019.

Kemenkes (2011). Profil Kesehatan Indonesia, Jakarta

Lulu Yunita (2016), Efektifitas Pendidikan Kesehatan Dengan Metode Ceramah Terhadap Tingkat Pengetahuan Ibu dalam Penanganan diare Balita di Sekitar UPT TPA Cipayung, Depok. Skripsi. UIN Syarif Hidayatullah Jakarta 